\title{
New races of Bremia lactucae on lettuce in Australia
}

\author{
D. S. Trimboli • Jacqueline Nieuwenhuis
}

Received: 20 November 2010 / Accepted: 24 July 2011 /Published online: 1 September 2011

(C) Australasian Plant Pathology Society Inc. 2011

\begin{abstract}
Three distinct patterns of virulence in Bremia lactucae were identified in samples of lettuce downy mildew collected between 2005 and 2010 in Australia. These are unique to Australia and it is proposed they be named AUS4, AUS5 and AUS6.
\end{abstract}

Keywords Bremia lactucae $\cdot$ Dm genes $\cdot$ Races $\cdot$ Sextet codes

The previous report on the development of a new race (previously pathotype) of B. lactucae on lettuce (Lactuca sativa) in Australia was published in 2004 (Trimboli 2004) in which the current races were listed as AUS1-3. Since 2004, several reports were received indicating that cultivars possessing the $D m 18$ resistance gene may no longer be resistant to the isolates of $B$. lactucae present in Australia and New Zealand. In spring 2004, the first observation that Dm 18 had definitely been overcome, was made in the field in Pukekohe, New Zealand where a range of crisphead (iceberg) cultivars with several resistance genes was being trialled (Trimboli unpublished). Subsequently a number of samples was collected from varying types of lettuce affected by downy mildew between 2005 and 2010 from south-east Queensland, southern \& eastern Victoria, South
Australia and coastal and inland New South Wales. The avirulence/virulence pattern of each sample was determined using the identical differential set of varieties proposed by the International Bremia Evaluation Board (IBEB). Recently, this differential set has been extended to include five new cultivars (Anon. 2009, 2010).

Analysis of the results of downy mildew samples on the differential set identified three new patterns of virulence (Table 1). It is proposed to designate isolates with these new patterns of virulence, races AUS4, AUS5 and AUS6. Each proposed race is distinct and its virulence pattern on the lettuce differential set does not resemble any of the patterns (and therefore the sextet codes) of races, Bl:1-27 or those of California CaIIa-VIII (Anon. 2009, 2010). Hence there remains a requirement for distinct Australian nomenclature. Table 1 lists the patterns of virulence and the sextet codes for all six races of Bremia in Australia. Although AUS4-6 have somewhat similar virulence patterns to $\mathrm{Bl}: 24$ and $\mathrm{B} 1: 25$, this does not mean that cultivars with resistance to these two European races will be resistant to AUS4-6. Dm6 is not broken by the Australian races whereas $D m 14$ and 15 are. The converse is true for the two European races. Table 2 lists the frequency of isolation and location for each of the new races. The three patterns of virulence were found in samples collected during consecutive years which is

D. S. Trimboli $(\bowtie)$

Ex Enza Zaden Australia Pty Ltd,

Narromine 2821 NSW, Australia

e-mail: dan.trimboli@bigpond.com

J. Nieuwenhuis

Enza Zaden Australia Pty Ltd,

Narromine 2821 NSW, Australia 
Table 2 Collection data for the new races of Bremia lactucae in Australia

\begin{tabular}{|c|c|c|c|}
\hline $\begin{array}{l}\text { Race: } \\
\text { Location: }\end{array}$ & AUS4 & AUS5 & AUS6 \\
\hline \multirow[t]{3}{*}{ NSW } & $\begin{array}{l}\text { Camden—September, } \\
2005\end{array}$ & Wallacia—May, 2007 & Cowra_June, 2008 \\
\hline & $\begin{array}{l}\text { Werombi-June, } \\
2006\end{array}$ & Cobbity—July, 2008 & \\
\hline & $\begin{array}{l}\text { Werombi-October, } \\
2006\end{array}$ & $\begin{array}{l}\text { Luddenham-July, } \\
2008\end{array}$ & \\
\hline \multirow[t]{10}{*}{ VIC } & Rosebud-May, 2008 & $\begin{array}{l}\text { Lindenow-April, } \\
2006\end{array}$ & $\begin{array}{l}\text { Geelong —August, } \\
2006\end{array}$ \\
\hline & $\begin{array}{l}\text { Werribee \#1-June, } \\
2008\end{array}$ & $\begin{array}{l}\text { Lindenow-August, } \\
2006\end{array}$ & Rosebud-May, 2007 \\
\hline & $\begin{array}{l}\text { Werribee \#2-June, } \\
2008\end{array}$ & $\begin{array}{l}\text { Lindenow-- } \\
\text { November, } \\
2006\end{array}$ & Rosebud-May, 2008 \\
\hline & & $\begin{array}{l}\text { Rosebud-January, } \\
2006\end{array}$ & $\begin{array}{l}\text { Cranbourne-April, } \\
2010\end{array}$ \\
\hline & & $\begin{array}{l}\text { Rosebud-March, } \\
2009\end{array}$ & Werribee-May, 2010 \\
\hline & & $\begin{array}{l}\text { Rosebud-February, } \\
2010\end{array}$ & $\begin{array}{l}\text { Werribee-June, } \\
2010\end{array}$ \\
\hline & & $\begin{array}{l}\text { Rosebud-March, } \\
2010\end{array}$ & \\
\hline & & $\begin{array}{l}\text { Werribee-November, } \\
2008\end{array}$ & \\
\hline & & Werribee-May, 2009 & \\
\hline & & $\begin{array}{l}\text { Werribee-December, } \\
2009\end{array}$ & \\
\hline \multirow[t]{2}{*}{ QLD } & Gympie_July, 2008 & $\begin{array}{l}\text { Lockyer Valley_July, } \\
2007\end{array}$ & $\begin{array}{l}\text { Toowoomba-April, } \\
2008\end{array}$ \\
\hline & & $\begin{array}{l}\text { Lockyer Valley_July, } \\
2010 \text { - Gympie_July, } 2008\end{array}$ & $\begin{array}{l}\text { Lockyer Valley- } \\
\text { August, } 2008\end{array}$ \\
\hline SA & & & Virginia_June, 2008 \\
\hline
\end{tabular}

necessary to designate a new race under the European system of identification (Anon. 2010). The results indicate that cultivars possessing the $\operatorname{Dm} 18$ gene will not provide resistance to the new races, AUS4-6. However there is a number of $D m$ genes, individually or in combination that will provide resistance to AUS4-6 (Table 1).

It should be noted that races AUS1-3 (mainly AUS2 and AUS3) may occasionally be present in field populations of $B$. lactucae, therefore the previous publication should be noted in conjunction to ensure which $D m$ gene(s) would be resistant to all six races (Trimboli 2004).

\section{References}

Anonymous (2009) Differential sets. http://www.worldseed.org/ cms/medias/file/TradeIssues/DiseasesResistance/Differentials/ Lettuce-downy_mildew.pdf (accessed 18/5/2011)

Anonymous (2010) Press release of the International Bremia Evaluation Board (IBEB). http://www.plantum.nl/plantum/persberichten/ 10-05-03.pdf (accessed 18/5/2011)

Trimboli DS (2004) A new pathotype of Bremia lactucae on lettuce in Australia. Australas Plant Pathol 33:605 